\title{
Nowy wymiar edukacji regionalnej na Górnym Śląsku
}

\author{
Wartości najbliższego człowiekowi dziedzictwa \\ kulturowego powinny być wykorzystywane \\ w edukacji szkolnej. Jeśli bowiem dziedzictwo \\ to jest nośnikiem wielorakich wartości, \\ nieodzownych dla rozwoju człowieka, to \\ uwzględnienie owego dziedzictwa w catym \\ procesie edukacji jest w petni zasadne
}

Wojciech Książek (2000, s. 4)

Streszczenie: Celem tego opracowania jest próba przedstawienia zmian w zakresie edukacji regionalnej na Górnym Śląsku w kontekście edukacji międzykulturowej z uwzględnieniem aspektu doskonalenia kadry pedagogicznej w tym zakresie. Artykuł przedstawia prawne uwarunkowania edukacji regionalnej w Polsce po okresie transformacji ustrojowej ze szczególnym uwzględnieniem prawa oświatowego. Głównym obszarem rozważań staje się edukacja regionalna i jej rola w środowiskach zróżnicowanych kulturowo. Kluczową rolę w edukacji regionalnej odgrywają nauczyciele - regionaliści. Autorka zwraca uwagę na potrzebę doskonalenia nauczycieli w tym zakresie.

Słowa kluczowe: edukacja regionalna, Górny Śląsk, edukacja wielokulturowa, edukacja międzykulturowa

\section{Wprowadzenie}

Górny Śląsk w historycznie ukształtowanych granicach jest obszarem transgranicznym rozciągającym się na terytorium trzech państw: Polski, Republiki Czeskiej i Słowacji. Jest regionem wielokulturowym, stanowiącym osobliwą przestrzeń. Przez wieki krzyżowały się tu trakty handlowe i ścierały wpływy: morawskie, czeskie, niemieckie i polskie. Nawarstwiały się tradycje wyznaniowe, narodowe, kulturowe i obyczajowe. W ponad tysiącletniej historii Śląska, wielokulturowość była zawsze obecna i przybierała różne barwy. Łą- 
czyła lub dzieliła ludzi wspólnota językowa, religijna, narodowa i państwowa. Od wieków mieszkali tu Polacy, Niemcy, Morawianie, Żydzi, współistnieli obok siebie katolicy, ewangelicy i ludność wyznania mojżeszowego. Świadczy o tym bogata spuścizna wielokulturowego dziedzictwa Górnego Śląska.

Staniczek (1996) wskazuje, że edukacja regionalna na Śląsku ma zatem znaczenie szczególne. To zintegrowany proces kształtujący i stabilizujący postawy wobec dziedzictwa przeszłości i problemów współczesnych własnego regionu. Pomaga w świadomym określeniu własnej tożsamości. Wiedza na temat własnego regionu i problemów w nim występujących stwarza szanse zrozumienia przez młodych ludzi problemów, z którymi borykają się współczesna Europa i świat. Zwłaszcza w aspekcie migracji i tworzenia się społeczeństw wielokulturowych. Śląsk jako region pogranicza może poszczycić się wartościami wypracowanymi przez lata i występującymi już w edukacji w tym zakresie.

Wielokulturowość czy międzykulturowość obecna w edukacji jest próbą doszukiwania się wspólnych cech w różnorodności oraz czerpania doświadczeń i wzorów z dorobku innych narodów. Pojęcie to w naturalny sposób dotyczy także edukacji szkolnej, gdyż na tym etapie życia człowieka kształtuje się w znacznej mierze jego światopogląd, a autorytet szkoły i nauczyciela ma decydujące, najczęściej pozytywne znaczenie (Nowak, 2008). Bez umiejętnego łączenia treści edukacji regionalnej z edukacją wielokulturową czy międzykulturową nie można dzisiaj wdrażać na Śląsku prawdziwego regionalizmu.

Edukacja wielokulturowa, jak podkreśla Książek (2000) pozwala młodym ludziom zrozumieć, że we współczesnym świecie jest możliwe współistnienie, czyli życie ze sobą, a przynajmniej obok siebie, ludzi, których na pozór dzielą: język, religia, tradycje czy historia ich narodów. Z kolei międzykulturowość jako zjawisko świadczy o tym, że ludzie na pozór różni potrafią współtworzyć świat swoich ojczyzn lokalnych, regionalnych i krajów. Edukacja międzykulturowa jest więc ukierunkowana na przeciwdziałanie powstawania i funkcjonowania stereotypów i uprzedzeń etnicznych, narodowych, religijnych, na wychowywanie w duchu otwartości, wzajemnego szacunku oraz zmianę odniesień w stosunku do „obcego”.

Opracowanie składa się z wprowadzenia, opisu uwarunkowań prawnych edukacji regionalnej w Polsce, prezentacji miejsca i roli edukacji regionalnej w środowisku zróżnicowanym kulturowo, a także przedstawia działania w zakresie edukacji regionalnej wprowadzone w szkołach na terenie miasta Rybnika. 
Celem opracowania jest próba przedstawienia zmian w zakresie edukacji regionalnej na Górnym Śląsku w kontekście edukacji wielokulturowej i międzykulturowej z uwzględnieniem aspektu doskonalenia kadry pedagogicznej w tym zakresie.

\section{Uwarunkowania prawne edukacji regionalnej}

Przemiany społeczno-polityczne po roku 1989 miały istotne znaczenie dla polskiej oświaty . Jednym z przejawów tego zjawiska był powrót do realizacji zagadnień związanych z edukacją regionalną. Uczestnicy V Kongresu Regionalnych Towarzystw Kultury we Wrocławiu w 1994 roku uznali, że edukacja regionalna jest w stanie obronić młodych ludzi przed uniformizacją ich życia, uratować odrębność, pomóc w powrocie do korzeni własnej kultury, stworzyć silny związek z rodzinną ziemią, przygotować do zaangażowanego działania dla środowiska, wyrobić postawę otwartości i tolerancji dla innych społeczeństw i kultur (Karta Regionalizmu Polskiego, 1994).

Uchwalona na V Kongresie Regionalnych Towarzystw Kultury Karta Regionalizmu Polskiego (Karta Regionalizmu Polskiego, 1994) określała ogólne zasady regionalizmu w Polsce. Wśród postulowanych działań znalazły się i te, które dotyczyły edukacji regionalnej w szkołach. W punkcie szóstym dokumentu czytamy: szczególna rola w podtrzymywaniu i ksztattowaniu świadomości lokalnej i regionalnej przypada systemowi edukacji. Programy nauczania szkót wszystkich szczebli powinny szeroko uwzględniać tematyke regionalna.

Podstawą prawną edukacji regionalnej w szkołach stał się dokument Ministerstwa Edukacji Narodowej Dziedzictwo kulturowe w regionie. Założenia programowe opublikowany w październiku 1995 roku. W dokumencie podkreślono, że głównym celem edukacji regionalnej w procesie dydaktyczno-wychowawczym jest ukształtowanie u uczniów poczucia własnej tożsamości regionalnej jako postawy zaangażowania się w funkcjonowanie własnego środowiska i autentycznego otwarcia się na inne społeczności i kultury (Dz.U. 2001, nr 61, poz. 625). Realizacja treści edukacji regionalnej stała się więc nakazem i obowiązkiem szkół. Był to pierwszy dokument, który tak precyzyjnie określał cele i zadania szkoły, proponował konkretne treści nauczania i formy realizacji przedmiotu. Od tego momentu rozpoczął się renesans edukacji regionalnej w polskich placówkach oświatowych.

Duże znaczenie w zakresie edukacji regionalnej w szkołach i doskonalenia kadry miała Rekomendacja R(85) Komitetu Ministrów do Krajów Członkow- 
skich dotyczaca edukacji w zakresie dziedzictwa (przyjęta przez Komitet Ministrów 17 marca 1998 r. na 623 spotkaniu zastępców ministrów) w zakresie szkolenia kadr nauczycielskich głosząca, że „edukacja w zakresie dziedzictwa zakłada z góry ścisłą więź z programami szkolnymi i właściwymi szkoleniami nauczycieli. Teoretyczne i praktyczne kursy doskonalenia, wszędzie gdziekolwiek jest to możliwe, powinny być organizowane zarówno dla nauczycieli, jak i dla specjalistów w dziedzinie kultury. Personel z obszarów dziedzictwa winien mieć wyrobioną świadomość problematyki odnoszącej się do edukacji w zakresie dziedzictwa, a także, jeśli to możliwe, winien być szkolony w zakresie zaspokajania potrzeb młodych uczestników". Dokument precyzował również zakres uprawnień administracyjnych odnoszący się do nauczycieli, a mianowicie umożliwiający im właściwe przygotowanie, wdrożenie i realizację, w możliwie najlepszych warunkach, projektów edukacyjnych w zakresie dziedzictwa. Zwracano również uwagę na przygotowanie materiałów szkoleniowych na odpowiednim poziomie odnoszących się do dziedzictwa kulturowego.

Rozporządzenie Ministra Edukacji Narodowej z 15 lutego 1999 roku w sprawie podstawy programowej kształcenia ogólnego wniosło do szkół podstawowych i gimnazjalnych nowość w zakresie edukacji regionalnej, a mianowicie realizację obowiązkowej ścieżki edukacyjnej: Edukacja Regionalna - Dziedzictwo Kulturowe w Regionie. Tak więc od roku 1999 na różnych przedmiotach lekcyjnych realizowano obowiązkową ścieżkę edukacji regionalnej. Główne cele edukacyjne ścieżki miały przede wszystkim kształtować poczucie tożsamości narodowej dzieci i młodzieży, ale również ważnym aspektem był kontakt ucznia z jego środowiskiem lokalnym.

W rozporządzeniu Ministra Edukacji Narodowej z dnia 23 grudnia 2008 roku w sprawie podstawy programowej wychowania przedszkolnego oraz kształcenia ogólnego w poszczególnych typach szkół (Dz.U. 2009, nr 4, poz. 17) pominięto edukację regionalną, a jej treści w niewielkim zakresie realizowane były w ramach wymagań szczegółowych z poszczególnych przedmiotów. Podobnie jest w chwili obecnej, gdzie nowa ustawa o systemie oświaty zepchnęła edukację regionalną na dalszy plan działań edukacyjnych.

\section{Miejsce i rola edukacji regionalnej w środowiskach zróżnicowanych kulturowo}

Górny Śląsk przez wiele stuleci poddany był silnym oddziaływaniom kulturowym, społecznym, politycznym i ekonomicznym płynącym z Czech, Moraw, 
Austrii i Niemiec. Na jego historyczne losy wpływ miała także żyjąca tutaj ludność żydowska. W ciągu wieków Górny Śląsk zmieniał przynależność państwową, był miejscem spotkania czy zderzenia wielu kultur, pozostawał w kręgu oddziaływania rozmaitych systemów politycznych i gospodarczych. Te historyczne uwarunkowania wpłynęły na obecny kształt i charakter Górnego Śląska. Wpływają zatem również na specyficzną strukturę edukacji regionalnej na Górnym Śląsku, gdzie „treści edukacji regionalnej powinny się wiązać w swoich działaniach edukacyjnych z krajobrazem, architekturą, zabytkami kultury duchowej i materialnej, gwarą, dialektem miejscowym, folklorem, legendami, sztuką ludową, historią, wiedzą o lokalnych bohaterach (osobach znaczących i wydarzeniach, kontaktami międzyludzkimi, przekazem międzypokoleniowym, obyczajowością społeczności, obcowaniem z przyrodą, życiem według rytmu przyrody itp.)" (Nikitorowicz, 2006, s. 106). Tylko takie ukierunkowanie edukacji regionalnej pozwoli rozpocząć proces dialogu edukacyjnego, wzmacniając siły jednostki przez poznanie i zrozumienie siebie i swojej najbliższej kultury i w efekcie pozwoli dostrzec odmienności, inne punkty widzenia oraz poszukiwanie sposobów wzajemnego rozumienia, porozumienia i współpracy (Nikitorowicz, 2006).

Edukacja regionalna stanowi istotny element rzeczywistości społecznej, ułatwiający wychowankowi odkrywanie jego tożsamości kulturowej i własnego miejsca w świecie, rozumiana jest także jako umożliwianie młodym ludziom poznawania własnego dziedzictwa kulturowego, wartości i treści regionalnych. Stanowi również naturalną i formalną odmianę osobowościowej formacji człowieka, która zorientowana jest na poznanie oraz umiłowanie najbliższego środowiska życia najpierw dzieci i młodzieży, a w przyszłości twórczych i aktywnych obywateli "małej ojczyzny” (Staniczek, 1996). Tożsamość człowieka wskazuje na jego udział w życiu społecznym, w kulturze, pozwala na własną identyfikację i interpretację. Wiedza na temat własnego regionu, umiejętność rozwiązywania problemów w nim występujących stanowi szansę zrozumienia problemów o charakterze kompleksowym.

Praktyka wielu krajów uczy, że najlepszym miejscem na tworzenie społeczeństw o prawidłowych relacjach w środowiskach zróżnicowanych kulturowo jest szkoła. Przykładem może być doświadczenie Niemców z ludnością turecką, która przybyła tam po II wojnie światowej. Na początku zastosowano wobec niej politykę „oświeconego apartheidu”, następnie podporządkowanie się kulturze niemieckiej aż wreszcie zrozumiano konieczność zachowania cech autonomicznych ludności napływowej dla dobra budowy wielokulturowego społeczeństwa (Niestolik, 2010). 
W krajach skandynawskich istnieje ustawowy obowiązek wielojęzycznego kształcenia dzieci. W Stanach Zjednoczonych, na mocy Civil Rights Act z 1964 roku, wydano nakaz, pod rygorem wstrzymania środków finansowych, naboru studentów bez oznak dyskryminacji rasowej, szkolenia nauczycieli i pedagogów oraz opracowywania programów wielokulturowych. Od roku 1972 istnieje także obowiązek studiowania wszystkich kultur, nałożony nie tylko na tych, którzy z nich pochodzą (Niestolik, 2010).

Pedagogika międzykulturowa jako nurt w wychowaniu społeczeństw wielonarodowych i wielokulturowych, jak twierdzą Lewowicki (1991), Nalaskowski (1993) oraz Ogrodzka-Mazur (1997), musi skupiać się nie tylko na pracy z cudzoziemcami, lecz także z własnymi obywatelami, by wzajemnie uczyli się szacunku, tolerancji, wzajemnego i pokojowego współżycia, czerpali doświadczenia z bogactwa własnych kultur. Decydujące znaczenie w pracy szkolnej ma wzajemne poznanie uczniów realizowane w czasie wycieczek i wymiany młodzieży. Często następuje wtedy przełamywanie stereotypów istniejących jeszcze przed podróżą czy wręcz zauroczenie krajem i ludźmi, o których mieliśmy zupełnie inne wyobrażenie. Edukacja regionalna i wielokulturowa jest antidotum na tę rzeczywistość i jednym z priorytetów programu w zreformowanej szkole. Urasta do podstawowych zadań i wyzwań współczesnej rodziny i szkoły.

Nadrzędnym celem edukacji regionalnej i międzykulturowej jest ukształtowanie trwałych więzi z mała ojczyzną, świadomość własnych korzeni, odnajdywanie w kulturze źródeł najistotniejszych wartości, zaangażowanie do aktywnego działania na rzecz środowiska. Edukacja regionalna i wielokulturowa ma za zadanie uświadomić młodzieży piękno najbliższej okolicy i miejsca zamieszkania, poczucie własnej tożsamości i oryginalności. Znajomość tradycji własnego regionu ułatwia orientację w środowisku, w którym żyje młodzież. Poznanie tradycji danej społeczności, jej wyjaśnianie i odtwarzanie, pozwala zrozumieć specyfikę kulturową ludzi zamieszkałych na danym terenie. Budzenie uczuć emocjonalnych w stosunku do małej ojczyzny ułatwia rozwijanie uczuć patriotycznych do kraju, w którym żyjemy. Realizacja treści regionalnych sprzyja korelacji międzyprzedmiotowej. Należy ją realizować łącząc kształcenie polonistyczne, historyczne, biologiczne i geograficzne.

\section{Edukacja regionalna w rybnickich szkołach podstawowych}

Rybnik jest przykładem miasta, które twórczo wykorzystuje ideę regionalizmu w nauczaniu i wychowaniu. Tworzy nowy wymiar edukacji regionalnej 
na Górnym Śląsku. W roku szkolnym 2016/2017, decyzją władz miasta, do rybnickich szkół podstawowych został wprowadzony przedmiot Edukacja regionalna w wymiarze jednej godziny tygodniowo w ramach tzw. godzin prezydenckich. Przedmiot realizowany jest do chwili obecnej we wszystkich klasach czwartych szkół podstawowych, dla których organem prowadzącym jest miasto Rybnik. Decyzja władz miasta o wprowadzeniu nowego przedmiot w szkołach spotkała się z zainteresowaniem regionalistów, środowisk nauczycielskich, ale również z przychylnością ze strony uczniów i rodziców.

Inicjatywa jest efektem współpracy miasta Rybnik z przedstawicielami stowarzyszenia DURŚ - Demokratycznej Unii Regionalistów Śląskich. Zajęcia prowadzone są przez nauczycieli historii, języka polskiego, geografii, nauczania początkowego i innych specjalności, którzy zostali odpowiednio przygotowani i przeszkoleni do prowadzenia zajęć przez Wojewódzki Ośrodek Metodyczny. Stowarzyszenie DURŚ uruchomiło pierwszą darmową śląską platformę edukacyjną „E-Rechtor”, która jest dedykowana przede wszystkim nauczycielom.

Intencją inicjatorów programu jest realizacja treści regionalnych w szkołach poprzez zabawę i przygodę. Ważnym elementem edukacyjnym są wycieczki terenowe uczniów po najbliższej okolicy. Dzieci poznają dziedzictwo kulturowe w środowisku, które ich otacza. Program koncentruje się wokół następujących kręgów tematycznych: moja rodzina, mój dom, moje sąsiedztwo, okolice, szkoła, czyli Śląsk w ujęciu historycznym i geograficznym. Zachęca uczniów do poznawania najbliższego otoczenia, historii swoich dzielnic, miasta, regionu. Rozbudza twórcze uczestnictwo w życiu kulturalnym. Kształtuje podstawę otwartości wobec ludzi i świata. Kształtuje tożsamość młodego człowieka, który jest emocjonalnie związany ze swoją ziemią i kulturą.

Od roku szkolnego 2017/2018 program Rybnik na Górnym Śląsku został wzbogacony, rozwinięty i oparty o dziedzictwo kulturowe w zakresie rewitalizacji. Jest zgodny z rozporządzeniem Ministra Edukacji Narodowej z dnia 14 lutego 2017 roku w sprawie podstawy programowej wychowania przedszkolnego oraz kształcenia ogólnego dla szkoły podstawowej (Dz.U. 2017, poz. 356). Wpisuje się również w kompleksowy program realizowany przez miasto Rybnik pn. Rewitalizacja miasta - nowa energia rybnickiej tradycji, współfinasowany z środków Unii Europejskiej w ramach Programu Operacyjnego Pomoc Techniczna 2014-2020. Jedną z ciekawszych propozycji tego projektu były właśnie działania edukacyjne skierowane do uczniów. Opracowano program edukacji regionalnej wspierający proces rewitalizacji 
w mieście. Jest on ciekawym uzupełnieniem programu Rybnik na Górnym Ślasku. Dla nauczycieli przygotowano podręcznik Energia tradycji. Podręcznik edukacji regionalnej dla nauczycieli autorstwa: E. Naparstek, N, Niestolika, A. Urbanek oraz materiały dydaktyczne (2018).

Działania edukacyjne realizowane w Rybniku to nowatorskie rozwiązania. To przykład synergii władz lokalnych, szeroko pojętego środowiska lokalnego, uczniów, nauczycieli, przedstawicieli nauki, pasjonatów regionalistów oraz wszystkich, którym leży na sercu zaszczepienie idei regionalnych wśród dzieci. Tak rozumiana edukacja w sposób całościowy oddziaływuje na umysł, emocje i wolę ucznia. Przyczynia się do kształtowania odpowiedzialności za region, siebie, najbliższą okolicę, otaczającą ucznia rzeczywistość. Wiąże go z nią intelektualnie i emocjonalnie. W ten sposób edukacja regionalna umożliwia kompleksowe, syntetyczne ujmowanie procesu nauczania i wychowania. Nie jest ograniczona tylko do przeszłości, ale ukierunkowana na współczesność i przyszłość. Pełni ważną funkcję wychowawczą w kształtowaniu postaw twórczych i aktywnych, odpowiedzialnych za kontakty społeczne w najbliższym środowisku, również z Obcymi i Innymi.

\section{Podsumowanie}

Edukacja regionalna wraz z edukacją wielo- i międzykulturową powinna stanowić w szkole część procesu kształcenia ogólnego. Zagadnienia te nabierają szczególnego znaczenia w dobie odrodzenia społeczności lokalnych, a wraz z tym kształtowania się emocjonalnych więzi ucznia ze swoim otoczeniem, z najbliższym środowiskiem. Codzienny widok z okna, droga do pracy, szkoły, krajobrazy, miejsca, ludzie, wydarzenia, teraźniejszość, przeszłość to wszystko składa się na treść edukacji regionalnej. Treści te i ich bliskość skłaniają w naturalny niemal sposób do wielozmysłowego poznawania i odkrywania najbliższego otoczenia ucznia. Stymulowania jego kreatywności i twórczego potencjału.

Nikitorowicz (2009) twierdzi, iż umiejętne powiązanie treści edukacji regionalnej z edukacją międzykulturową i wielokulturową stanowi dzisiaj w edukacji nową jakość. Zaś wychowanie twórczego i pewnie poruszającego się w świecie wartości człowieka o ukształtowanej tożsamości to jedno z ważnych zadań współczesnej szkoły. W aspekcie świata naszych małych ojczyzn, jak i ojczyzny regionalnej edukacja wielokulturowa może przyczynić się do lokalnego pojednania. Jan Paweł II powiedział w roku 1983 na Górze św. Anny: „Ziemia ta wciąż potrzebuje wielorakiego pojednania”. 
Wielkim skarbem naszego regionu jest jego zróżnicowanie kulturowe i to zarówno w aspekcie historycznym, jak i obecnie. To bezcenna wartość, która stanowi podłoże edukacji, zwłaszcza edukacji regionalnej na Śląsku. Jakże aktualne są słowa Henryka Mühlpforta, który już przed kilkoma wiekami nazwał Śląsk „szmaragdem Europy”. Szmaragd to szlachetny kamień, który jest bardzo drogocenny, bo składa się z wielkiej liczby scalonych w nierozdzielną całość elementów. Andreas Gryphius dodawał, że jest to kraina ludzi kochających rozum i myślących sercem, czyli różnych, co jednak stanowi walor, a nie powód do zmartwień. Wybitny śląski kapłan ks. Emil Michał Szramek (Szramek, 1998, s. 45), beatyfikowany w roku 1999 przez papieża Jana Pawła II, głosił, iż Ślązak jest jak grusza na miedzy, która rodzi po dwóch stronach. Oby dzięki pracy współczesnych nauczycieli kolejne pokolenia uczniów śląskich szkół były wychowywane w duchu wielokulturowości. Jest to bardzo potrzebne naszej śląskiej ziemi i jeszcze bardziej naszemu krajowi. To nowy wymiar edukacji regionalnej na Śląsku.

\section{Bibliografia}

Baka, W. 2004. W tyglu transformacji ustrojowej. Szkice i komentarze. Warszawa: Książka i Wiedza.

Dziedzictwo kulturowe w regionie. Założenia programowe. Dz.U. 2001, nr 61, poz. 625.

Dziewula, D. 1995. Polityka oświatowa wspólnoty europejskiej. Warszawa: Wydawnictwo Akademickie „Żak”.

Karta Regionalizmu Polskiego, Wrocław 1994r. http://regionalizmpolski.pl/ files/karta_regionalizmu.pdf (20.02.2019).

Książek, W. 2000. O edukacji regionalnej - dziedzictwie kulturowym w regionie. Biblioteczka Reformy Ministerstwo Edukacji Narodowej. 24, ss. 4-80.

Lewowicki, T. 1991. W stronę paradygmatu edukacji podmiotowej. Edukacja. 1, ss. 6-16.

Lewowicki, T. 2002. W poszukiwaniu modelu edukacji międzykulturowej. W: Lewowicki, T., Nikitorowicz, J., Pilch i T., Tomiuk, S. red. Edukacja wobec tadu globalnego. Warszawa: Wydawnictwo Akademickie „Żak”, ss. 15-32.

Nalaskowski, S. 1993. Humanizm i podmiotowość w wychowaniu. Toruń: Wydawnictwo Adam Marszałek.

Niestolik, N. 2010. Nauczyciel regionalista na Górnym Śląsku - refleksja historyczna, spojrzenie w przyszłość. Edukacja regionalna - doświadczenia. 
W: Juszczyk, S. i Morańska D. red. Historia, instytucjonalizacja i perspektywy ksztatcenia nauczycieli na Ślasku: jubileusz 80-lecia. Katowice: UŚ, Ss. $255-160$.

Nikitorowicz, J. 1995. Pogranicze, tożsamość, edukacja międzykulturowa. Białystok: Wydawnictwo Uniwersyteckie „Trans Humana”.

Nikitorowicz, J. 2009. Edukacja regionalna i międzykulturowa. Warszawa: Wydawnictwa Akademickie i Profesjonalne. Grupa Kapitałowa WSiP. Nowak, M. 2008. Teorie i koncepcje wychowania. Warszawa: WAiP.

Ogrodzka-Mazur, E. 1997. Tożsamość własna a społeczne funkcjonowanie młodzieży regionu pogranicza. W: Lewowicki, T. i Ogrodzka-Mazur, E. red. Osobowość i społeczne funkcjonowanie młodzieży regionu Podbeskidzia. Katowice: UŚ, ss. 31-44.

Rozporządzenie Ministra Edukacji Narodowej z dnia 14 lutego 2017 r. w sprawie podstawy programowej wychowania przedszkolnego oraz podstawy programowej kształcenia ogólnego dla szkoły podstawowej, w tym dla uczniów z niepełnosprawnością intelektualną w stopniu umiarkowanym lub znacznym, kształcenia ogólnego dla branżowej szkoły I stopnia, kształcenia ogólnego dla szkoły specjalnej przysposabiającej do pracy oraz kształcenia ogólnego dla szkoły policealnej (Dz.U. 2017, poz. 356).

Rozporządzenie Ministra Edukacji Narodowej z dnia 15 lutego 1999 r. w sprawie podstawy programowej kształcenia ogólnego (Dz.U. 1999, poz.129). Rozporządzenie Ministra Edukacji Narodowej z dnia 23 grudnia 2008 r. w sprawie podstawy programowej wychowania przedszkolnego oraz kształcenia ogólnego w poszczególnych typach szkół (Dz.U. 2009, poz. 17). Staniczek, Ł. 1996. Koncepcja edukacji regionalnej na Śląsku. Szkic niektórych problemów W: Edukacja regionalna na Ślasku. Od tradycji do nowoczesności. Katowice: Wojewódzki Ośrodek Metodyczny, ss. 173-189.

Szczepański, J. 1989. Społeczne uwarunkowania rozwoju oświaty. Warszawa: WSiP.

Szramek, E. 1934. Śląsk jako problem socjologiczny. Roczniki Towarzystwa Przyjaciót Nauk na Śląsku. 4, ss. 22-95.

\section{A new dimension of regional education in Upper Silesia}

Abstract: The aim of this elaboration is an attempt to illustrate the changes in the field of regional education in the Upper Silesia in the context of multicultural and intercultural education with reference to the aspect of teachers' development in 
this regard. The article presents legal determinants of regional education in Poland after political transformation period with particular focus on education law. The main field of discussion becomes regional education and its role in culturally diverse environment. Teachers play the key role in regional education - regionalists. The author pays attention to the need of teachers' development in this respect.

Keywords: regional education, Upper Silesia, multicultural education, intercultural education

Translated by Teresa Szymik 